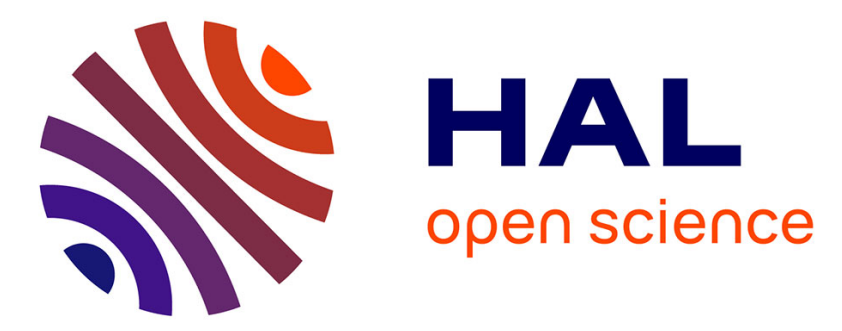

\title{
Sources, trends, and fate of methane in shallow aquifers of Alberta, Canada
}

\author{
Pauline Humez, Florian Osselin, Wolfram Kloppmann, Cynthia Mcclain, \\ Michael Nightingale, Bernhard Mayer
}

\section{- To cite this version:}

Pauline Humez, Florian Osselin, Wolfram Kloppmann, Cynthia Mcclain, Michael Nightingale, et al.. Sources, trends, and fate of methane in shallow aquifers of Alberta, Canada. EGU General Assembly 2020, May 2020, Online, France. 10.5194/egusphere-egu2020-10777 . hal-03554429

\author{
HAL Id: hal-03554429 \\ https://hal.science/hal-03554429
}

Submitted on 4 Feb 2022

HAL is a multi-disciplinary open access archive for the deposit and dissemination of scientific research documents, whether they are published or not. The documents may come from teaching and research institutions in France or abroad, or from public or private research centers.
L'archive ouverte pluridisciplinaire HAL, est destinée au dépôt et à la diffusion de documents scientifiques de niveau recherche, publiés ou non, émanant des établissements d'enseignement et de recherche français ou étrangers, des laboratoires publics ou privés. 
EGU2020-10777

https://doi.org/10.5194/egusphere-egu2020-10777

EGU General Assembly 2020

(c) Author(s) 2022. This work is distributed under

the Creative Commons Attribution 4.0 License.

\title{
Sources, trends, and fate of methane in shallow aquifers of Alberta, Canada
}

\author{
Pauline Humez ${ }^{1}$, Florian Osselin ${ }^{1,4}$, Wolfram Kloppmann², Cynthia McClain ${ }^{3}$, Michael Nightingale ${ }^{1}$, \\ and Bernhard Mayer ${ }^{1}$ \\ ${ }^{1}$ Department of Geoscience, University of Calgary, Calgary, Alberta Canada T2N 1N4 (phumez@ucalgary.ca) \\ ${ }^{2}$ BRGM, French Geological Survey, 45030 Orléans, France \\ ${ }^{3}$ Alberta Environment and Parks, Calgary, Alberta, Canada, T2E 7J2 \\ ${ }^{4}$ Institut des Sciences de la Terre d'Orléans, UMR 7327, Université d'Orléans/BRGM/CNRS, 45100 France
}

Due to concerns regarding potential impacts of the development of natural gas from unconventional hydrocarbon resources on groundwater systems in North America and elsewhere, it has been crucial to improve methods of Environmental Baseline Assessment (EBA). Any subsequent deviations from the EBA could indicate migration of natural gas into the monitored groundwater systems. In collaboration with Alberta Environment and Parks, over 800 groundwater samples have been collected from dedicated monitoring wells since 2006 resulting in an extensive high-quality database of aqueous and gaseous geochemical and isotopic compositions. Because methane is the main component of natural gas, it had been the principal target of our groundwater studies. Our objectives were a) to assess the occurrence of methane in groundwater throughout the province of Alberta (Canada), b) to use isotope techniques to track the predominant sources of methane, c) to use a combination of chemical and multi-isotopic techniques and models to assess the fate of methane in groundwater, and d) to use probability for predicting the presence of methane in groundwater based on hydrogeochemical parameters in regions where no gas data exist.

Methane was found to be ubiquitous in groundwater samples throughout the province of Alberta with concentrations varying from $2.910^{-4}$ to $>2.4 \mathrm{mmol} / \mathrm{l}$. The highest methane concentrations were found in $\mathrm{Na}-\mathrm{HCO}_{3}$ and $\mathrm{Na}-\mathrm{Cl}$ water-types where the sulfate concentrations were $<1 \mathrm{mmol} / \mathrm{l}$. Analyses of the isotopic compositions of sulfate, dissolved inorganic carbon (DIC) and methane revealed that in some groundwater systems bacterial sulfate reduction occurred $\left(\delta^{34} \mathrm{~S}_{\mathrm{SO} 4}{ }^{>+10 \%}\right.$ associated with lowest sulfate concentrations) and evidence for methane oxidation was also detected (highest $\delta^{13} \mathrm{C}_{\mathrm{CH} 4}$ values $>055 \%$ associated with lowest methane concentrations). Moreover, some $\delta^{13} C_{D I C}$ values were as high as $+13.8 \%$ associated with the highest methane concentrations. A geochemical and multi-isotope model using long-term monitoring data was developed and revealed two different sources of methane: 1) microbial methane resulting from insitu methanogenesis within the aquifer for a subset of the samples; 2) migration of microbial methane into aquifers characterized by various redox conditions, followed by methane oxidation potentially coupled with bacterial sulfate reduction within sulfate-rich zones causing a pseudo- 
thermogenic carbon isotopic fingerprint for the remaining methane. So far, no evidence of unambiguously thermogenic methane in the groundwater samples collected from dedicated monitoring wells has been found. Efforts to assess the probability of regional occurrence of methane in groundwater systems in Alberta have then focused on a model for methane prediction model based on logistic regression (LR) for regions of Alberta where no gas data exist. Using basic hydrogeochemical parameters such as occurrence of electron donors, well depth and total dissolved solids of groundwater, the LR approach shows excellent performance metrics e.g. model sensitivity, specificity $>80 \%$ regarding the prediction of methane occurrence in groundwater of Alberta. 